\title{
Topical acyclovir in the treatment of initial genital herpes
}

\author{
R N THIN,* JOAN M NABARRO,† J DAVIDSON PARKER,* AND \\ A PAUL FIDDIAN \\ From the Departments of Genital Medicine, *St Bartholomew's Hospital and the +Central Middlesex \\ Hospital; and the $¥$ Department of Clinical Immunology and Chemotherapy, Wellcome Research \\ Laboratories, Beckenham, Kent
}

SUMMARY In a double-blind randomised placebo-controlled trial of topical acyclovir in initial (first episode) genital herpes 18 patients received acyclovir ointment and 22 matching placebo ointment. Acyclovir significantly reduced the duration of viral shedding from external and all genital lesions, the duration of vesicles, the time to crusting, the time to complete healing of external and all genital lesions, new lesion formation, and the duration of pain, itching, and all symptoms combined for all patients. In female patients alone the time to crusting was not significantly different and the duration of pain only approached significance but the effects were otherwise the same as for all patients. No patients reported any adverse effects of treatment Topical acyclovir is well tolerated and effective in treating initial genital herpes.

\section{Introduction}

Genital infection with herpes simplex virus is increasing in incidence. ${ }^{1}$ The primary or initial attack may be a severe illness with multiple genital and anorectal lesions appearing in crops from two to four weeks and occasionally with urinary retention and constipation due to pain and neurological involvement, root pains, and more distant disease such as adenitis and hepatitis. Such severe cases warrant admission to hospital and may benefit from intravenous treatment. ${ }^{2}$ Many initial attacks are milder and do not merit admission to hospital though the patient would benefit from treatment to shorten the symptomatic illness and the period of viral shedding.

Many remedies have been tried for the treatment of herpes simplex infection and their number reflects their doubtful efficacy. Acyclovir (Zovirax, Wellcome), an acyclic nucleoside guanosine derivative, has low toxicity and high antiviral activity in vitro, especially against herpes simplex virus types 1 and 2. Intravenous acyclovir is effective in the treatment of severe initial episodes of genital herpes. ${ }^{23}$ We report the results of a double-blind placebocontrolled trial of topical acyclovir in outpatients

Address for reprints: Dr $\mathbf{R} N$ Thin, Department of Genitourinary Medicine, St Thomas's Hospital, London SE1 7EH

Accepted for publication 24 September 1982 attending St Bartholomew's Hospital and the Central Middlesex Hospital, London, with initial attacks of genital herpes.

\section{Patients and methods}

STUDY POPULATION

Male and female patients aged 16 years and over with typical herpetic lesions present for a maximum of five days were invited to participate in the trial. All who agreed to take part gave informed consent. 을 Criteria for exclusion were: antiviral treatment $₹$ during the preceding 14 days, concurrent infections $\frac{\mathrm{O}}{5}$ which might confuse the assessment of clinical progress, pregnancy, and in women no reliable method of contraception (namely an intrauterine $N$ device or oral contraceptive). Local ethics com- $\infty$ mittees approved the protocol for the study.

VIRAL CULTURE

Patients were examined clinically and investigated for genitourinary and related infection as described. ${ }^{4}{ }^{5}$ Swabs for viral culture were taken from repre- ? sentative lesions and where possible from the cervix in women, transported to the laboratory in Hanks balanced salt solution, and inoculated either on to human embryonic lung cells or embryonic kidney cells. 


\section{TREATMENT ALLOCATION}

Patients were randomly allocated to treatment or placebo groups by a random numbered sequence and instructed to apply five times daily either $5 \%$ acyclovir in a polyethylene glycol base or base alone; both preparations were packed in identical tubes. Patients were requested to return twice a week for two weeks and weekly thereafter until healing was complete. At each visit they were examined clinically and further swabs collected for viral culture. Most of the clinical examinations were undertaken by one doctor at each centre (JMN and JDP).

\section{STATISTICAL ANALYSIS}

Statistical analysis was by means of a one-tailed log rank analysis except where indicated in table IV, where Fisher's exact test was used. Medians were used to present most of the data as many variables had a skewed distribution and numbers were small.

\section{Results}

Forty patients took part in the trial: eighteen were treated with acyclovir (group A) and 22 with the placebo (group B); 19 attended the Central Middlesex Hospital (centre 1) and $21 \mathrm{St}$ Bartholomew's Hospital (centre 2). The sex ratios and age ranges of patients treated with acyclovir or placebo were similar (table I). The lesions were of similar severity in the two groups. The duration of lesions before presentation and the number of patients with other infections, complaining of pain, and with vesicles alone were similar in the two treatment groups; there were more patients with ulcers alone in the group treated with acyclovir (10 compared with seven) and all six patients with crusts already present were in the placebo group (table I).

Thirty-four patients had virus recovered from cultures performed at entry, 14 in group A and 20 in group B (table I). All those with negative culture results had typical-looking lesions. At centre 2, 84\% of patients had herpes simplex virus type 2 and $16 \%$ had type 1. Fifteen of these isolates were tested for sensitivity to acyclovir and the median infective dose
TABLE I Details on entry to trial of treatment with acyclovir (group A) compared with placebo (group B) in patients with genital herpes

\begin{tabular}{lcc}
\hline & $\begin{array}{l}\text { Group } A \\
(n=18)\end{array}$ & $\begin{array}{l}\text { Group } B \\
(n=22)\end{array}$ \\
\hline No of patients from: & & \\
Centre 1 & 9 & 10 \\
Centre 2 & 9 & 12 \\
No of women & 11 & 14 \\
No of men & 7 & 8 \\
Mean age (range) in years & $21 \cdot 9(18-30)$ & $23 \cdot 8(16-32)$ \\
Mean duration of lesions (days) & $3 \cdot 3$ & $3 \cdot 3$ \\
Extent score* & $2 \cdot 1$ & $2 \cdot 2$ \\
No of patients with: & 2 & 2 \\
Other infectionst & 17 & 21 \\
Pain & 8 & 9 \\
Vesicles only & 10 & 7 \\
Ulcers only & 0 & 6 \\
Crusts & 14 & 20 \\
Positive culture results at entry & \\
Positive culture results at & 8 & 11 \\
$\quad$ centre 2: & 7 & 2 \\
$\quad$ HSV type 2 (84\%) & 1 & \\
HSV type 1 (16\%) &
\end{tabular}

*Subjective assessment of severity

tCandida (2), Trichomonas vaginalis, warts

$\left(\mathrm{ID}_{50}\right)$ values were in the usual ranges (mean values $0.34 \mu \mathrm{mol} / \mathrm{l}$ for $12 \mathrm{HSV}$ type 2 isolates and 0.028 $\mu \mathrm{mol} / \mathrm{l}$ for three HSV type 1 isolates). Four of seven isolates cultured after the start of treatment showed a $25 \%$ reduction in sensitivity but three of these were from patients in group B.

\section{RESPONSE TO TREATMENT}

Viral shedding-This was notably shorter for group A than for group B (table II and fig 1). Differences were more pronounced for external lesions and less notable when all (external and internal) lesions were considered in women.

Healing - This was appreciably faster in patients in group A than in those in group B (table III and fig 2). The median value for healing of all lesions in all patients in group A was nine days compared with 13.5 days for those in group B. Furthermore, there was little new lesion formation among the actively treated patients $(6 \%)$ compared with those given placebo $(45 \%)$.

TABLE II Duration of viral shedding in patients treated with acyclovir (group A) and those given placebo (group B)

\begin{tabular}{|c|c|c|c|c|c|c|}
\hline & \multicolumn{3}{|c|}{ All patients } & \multicolumn{3}{|l|}{ Women } \\
\hline & Group $A$ & Group B & $p$ value & Group $A$ & Group B & $p$ value \\
\hline \multicolumn{7}{|l|}{ Duration of viral shedding*: } \\
\hline External genital lesions & 2 & 7 & $<0.001$ & 3 & 7 & $<0.05$ \\
\hline All lesions & 2 & 9 & $<0.05$ & 3 & 9 & NS \\
\hline
\end{tabular}

* Median values in days

NS $=$ not significant 


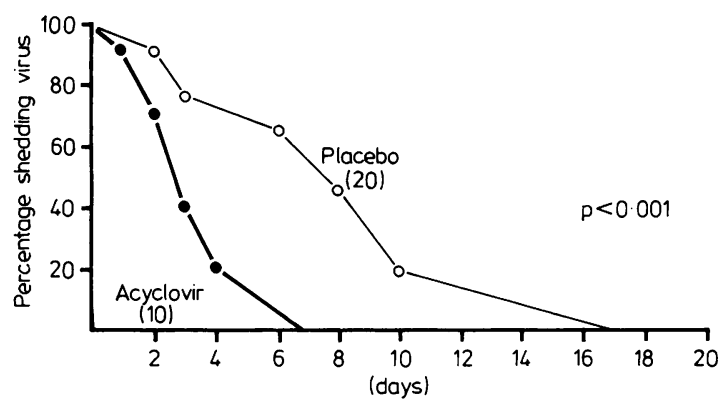

FIG 1 Duration of viral shedding from external genital lesions

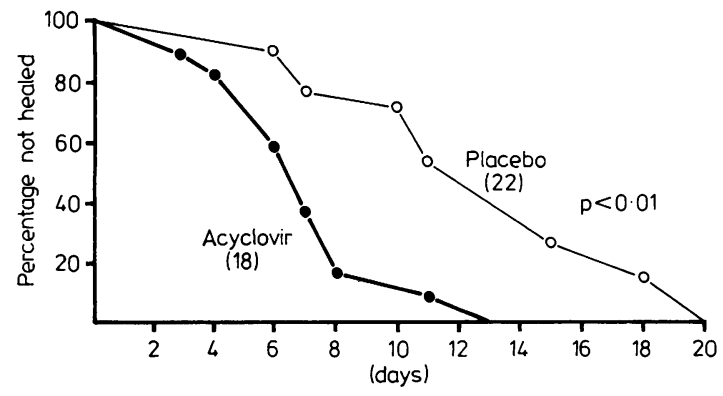

FIG 2 Time to healing of original external genital lesions
Symptomatic response-Most patients complained of pain and itching or irritation. These symptoms are shown separately in table IV. They had a shorter duration in patients in group $\mathbf{A}$ than in those in group B. Other symptoms were less common but when all symptoms combined are considered their duration was also shorter with a median of five days in patients in group A compared with 10 days in the remainder (fig 3).

Observer interaction-As two centres participated in the trial interaction between them was examined. Of all the indices assessed in tables II-IV a significant difference was noted only for "time to complete healing" for all patients and "duration of vesicles" for women.

Side effects-No patient reported any side effect in either treatment group.

\section{Discussion}

These results resemble those reported in a similar multicentre trial of topical acyclovir among patients with primary genital herpes treated in the USA by Corey et al. ${ }^{6}$ Their findings were presented in a slightly different manner but duration of pain, itching, viral shedding, and lesions was significantly shorter in patients treated with acyclovir than in those given placebo. In the same report faster healing (in men) and reduced viral shedding were noted in recurrent genital herpes. In contrast a report of

TABLE III Lesion progression and healing of genital herpes in patients treated with acyclovir (group A) and given placebo (group B)

\begin{tabular}{|c|c|c|c|c|c|c|}
\hline & \multicolumn{3}{|c|}{ All patients } & \multicolumn{3}{|l|}{ Women } \\
\hline & Group $A$ & Group B & $p$ value & Group $A$ & Group B & $p$ value \\
\hline $\begin{array}{l}\text { Duration of vesicles* } \\
\text { Time to crusting* }\end{array}$ & $\begin{array}{l}2 \\
5\end{array}$ & 2 & $\begin{array}{l}<0.05 \\
<0.05\end{array}$ & $\begin{array}{l}1 \\
6\end{array}$ & 2 & $\begin{array}{l}<0.05 \\
\text { NS }\end{array}$ \\
\hline $\begin{array}{l}\text { Time to complete healing*: } \\
\text { External genital lesions } \\
\text { All lesions } \\
\text { New lesion formation }(\%)\end{array}$ & $\begin{array}{l}7 \\
9 \\
6\end{array}$ & $\begin{array}{l}12 \\
13 \cdot 5 \\
45\end{array}$ & $\begin{array}{l}<0.01 \\
<0.05 \\
<0.01 t\end{array}$ & $\begin{array}{l}7 \\
9 \\
9\end{array}$ & $\begin{array}{l}15 \cdot 5 \\
17 \\
57\end{array}$ & $\begin{array}{l}<0.001 \\
<0.05 \\
<0.05\end{array}$ \\
\hline
\end{tabular}

*Median values in days

tFisher's Exact Test

$\mathrm{NS}=$ not significant

TABLE IV Duration of symptoms of genital herpes in patients treated with acyclovir (group A) and those given placebo (group B)

\begin{tabular}{|c|c|c|c|c|c|c|}
\hline & \multicolumn{3}{|c|}{ All patients } & \multicolumn{3}{|l|}{ Women } \\
\hline & Group $A$ & Group B & $p$ value & Group $A$ & Group B & $p$ value \\
\hline $\begin{array}{l}\text { Duration of pain* } \\
\text { Duration of itching* } \\
\text { Duration of all symptoms combined* }\end{array}$ & $\begin{array}{l}4 \\
2 \\
5\end{array}$ & $\begin{array}{r}7 \\
6 \\
10\end{array}$ & $\begin{array}{l}<0.01 \\
<0.01 \\
<0.01\end{array}$ & $\begin{array}{l}5 \\
2 \\
6\end{array}$ & $\begin{array}{l}10 \\
10 \\
10\end{array}$ & $\begin{array}{l}0.08 \\
0.001 \\
<0.05\end{array}$ \\
\hline
\end{tabular}

*Median values in days 


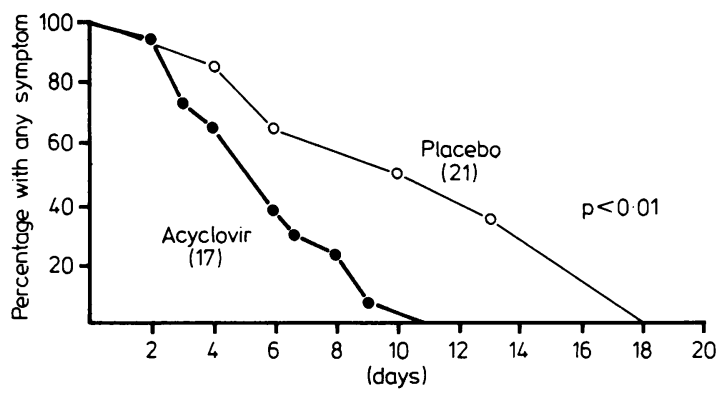

FIG 3 Duration of all symptoms combined

topical $5 \%$ acyclovir for the treatment of labial herpes simplex showed that duration of viral shedding was shortened but there was no effect on healing. ${ }^{7}$

Trials of intravenous acyclovir have shown a good response. Fife et $a \beta$ in Seattle, USA, reported a shorter duration of viral shedding, lesions, and local symptoms in patients treated with acyclovir compared with those given placebo. Mindel et $a l^{2}$ in London found significantly shorter median times for healing and viral shedding in patients treated with acyclovir than in those given placebo and significantly less new lesion formation in the first group. All these findings are similar to our own. Mindel et $a f^{2}$ also reported that the duration of symptoms was shorter with acyclovir than with placebo, but some of the differences in duration appeared to be less significant, notably of pain, than in the present study. The patients studied by Mindel et $a l^{2}$ had severe disease requiring admission to hospital and symptomatic treatment, unlike our outpatients. This may explain the differences, but the subjective assessment of symptoms by small numbers of patients is obviously open to variation.

We conclude that topical acyclovir appears to be a safe and, in the short term, effective preparation for the treatment of moderately severe initial attacks of genital herpes, which can be managed without admission to hospital. It is worth emphasising that topical acyclovir shortened the period of viral shedding; this has advantages to the patient and is probably of epidemiological importance. Further evaluation of acyclovir is obviously indicated. An improved topical formulation (acyclovir cream) and orally administered acyclovir are presently under study in this country.

We thank Professor Raymond Heath and Dr David McSwiggan, for their excellent help and support with viral cultures, and the clinic staff for their assistance. We also thank Mrs C A Burke, Clinical Research Division, Wellcome Research Laboratories, for the statistical analysis, and $\operatorname{Dr} \mathbf{P}$ Collins, Antiviral Chemotherapy Section, Wellcome Research Laboratories, for the sensitivity testing.

This paper was presented at the Spring meeting of the MSSVD at St Helier, Jersey, May 1982.

\section{References}

1. Anonymous. Sexually transmitted disease surveillance $1980 . \mathrm{Br}$ Med J 1982; 284: 124.

2. Mindel A, Adler MW, Sutherland S, Fiddian AP. Intravenous acyclovir treatment for primary genital herpes. Lancet $1982 ; \mathrm{i}: 697-700$.

3. Fife KH, Corey L, Keeney RE, et al. Double-blind placebocontrolled trial of intravenous acyclovir for severe primary genital herpes. 21st Interscience Conference on Antimicrobial Agents and Chemotherapy, Chicago, Illinois, 4-6 Nov 1981. Abstract 29.

4. Thin RN, Leighton M, Dixon MJ. How often is genital yeast infection sexually transmitted? $\mathrm{Br}$ Med J 1977; ii: 93-4.

5. Simmons PD. Podophyllin $10 \%$ and $25 \%$ in the treatment of ano-genital warts-a comparative double-blind study. $\mathrm{Br} J$ Vener Dis 1981;57:208-9.

6. Corey L, Nahmias AJ, Guinan ME, et al. A trial of topical acyclovir in genital herpes simplex virus infection. $N$ Engl $J$ Med 1982;306: 1313-9.

7. Spruance SL, Schnipper LE, Overall JC, et al. Treatment of herpes simplex labialis with topical acyclovir in polyethylene glycol. J Infect Dis 1982; 146:85-90. 